\title{
Phytochemical Profile and In Vitro Antioxidant, Antimicrobial, Vital Physiological Enzymes Inhibitory and Cytotoxic Effects of Artemisia jordanica Leaves Essential Oil from Palestine
}

\author{
Nidal Jaradat (1)
}

check for

updates

Citation: Jaradat, N. Phytochemical Profile and In Vitro Antioxidant, Antimicrobial, Vital Physiological Enzymes Inhibitory and Cytotoxic Effects of Artemisia jordanica Leaves Essential Oil from Palestine. Molecules 2021, 26, 2831. https://doi.org/ $10.3390 /$ molecules26092831

Academic Editors: Ana Paula Duarte, Ângelo Luís and Eugenia Gallardo

Received: 20 March 2021

Accepted: 9 May 2021

Published: 10 May 2021

Publisher's Note: MDPI stays neutral with regard to jurisdictional claims in published maps and institutional affiliations.

Copyright: (C) 2021 by the author. Licensee MDPI, Basel, Switzerland. This article is an open access article distributed under the terms and conditions of the Creative Commons Attribution (CC BY) license (https:// creativecommons.org/licenses/by/ $4.0 /)$.
Department of Pharmacy, Faculty of Medicine and Health Sciences, An-Najah National University, P.O. Box 7, Nablus 00970, Palestine; nidaljaradat@najah.edu

Abstract: Artemisia jordanica (AJ) is one of the folkloric medicinal plants and grows in the arid condition used by Palestinian Bedouins in the Al-Naqab desert for the treatment of diabetes and gastrointestinal infections. The current investigation aimed, for the first time, to characterize the (AJ) essential oil (EO) components and evaluate EO's antioxidant, anti-obesity, antidiabetic, antimicrobial, anti-inflammatory, and cytotoxic activities. The gas chromatography-mass spectrometer (GC-MS) technique was utilized to characterize the chemical ingredients of (AJ) EO, while validated biochemical approaches were utilized to evaluate the antioxidant, anti-obesity and antidiabetic. The microbicidal efficacy of (AJ) EO was measured utilizing the broth microdilution assay. Besides, the cytotoxic activity was estimated utilizing the (MTS) procedure. Finally, the anti-inflammatory activity was measured utilizing a COX inhibitory screening test kit. The analytical investigation revealed the presence of 19 molecules in the (AJ) EO. Oxygenated terpenoids, including bornyl acetate $(63.40 \%)$ and endo-borneol (17.75\%) presented as major components of the (AJ) EO. The EO exhibited potent antioxidant activity compared with Trolox, while it showed a weak anti-lipase effect compared with orlistat. In addition, the tested EO displayed a potent $\alpha$-amylase suppressing effect compared with the positive control acarbose. Notably, the (AJ) EO exhibited strong $\alpha$-glucosidase inhibitory potential compared with the positive control acarbose. The EO had has a cytotoxic effect against all the screened tumor cells. In fact, (AJ) EO showed potent antimicrobial properties. Besides, the EO inhibited the enzymes COX-1 and COX-2, compared with the anti-inflammatory drug ketoprofen. The (AJ) EO has strong antioxidant, antibacterial, antifungal, anti- $\alpha$-amylase, anti- $\alpha$-glucosidase, and COX inhibitory effects which could be a favorite candidate for the treatment of various neurodegenerative diseases caused by harmful free radicals, microbial resistance, diabetes, and inflammations. Further in-depth investigations are urgently crucial to explore the importance of such medicinal plants in pharmaceutical production.

Keywords: Artemisia jordanica; essential oil; antioxidant; anti-obesity; antidiabetic; antimicrobial; anti-inflammatory; cytotoxicity

\section{Introduction}

For centuries, humankind has utilized various plant species for many medical, nutraceutical, flavor, food additive, and cosmetics applications. Medicinal herbs are in high demand for primary health care in many countries of the developing and developed world because they have fewer adverse effects, are safer, and some of them are more effective than synthetic medications [1]. Many plants contain extractable secondary metabolic compounds with wide biological activity and many of the recently used pharmaceutical formulations are isolated from plants [2].

Essential oils (EOs) are combinations of various aromatic volatile secondary metabolic molecules that are mainly isolated from plants. They have various biologicals effects including antioxidant, antimicrobial, anticancer, digestive enzyme inhibitory, anti-inflammatory, anthelmintic, and many others [3]. Commercially, EOs are used in the manufacturing of 
hygienic products, food flavorings, beverages, household products, soaps, pharmaceuticals, perfumes, cosmetics, and other products [4].

These days, EOs have been thoroughly investigated as potential antioxidant agents to replace synthetic ones. In fact, EOs are mixtures of oxygenated terpenoids, monoterpene, sesquiterpenes, phenols, and other molecules. In most cases, the antioxidant activity of the EOs can be easily explained by the presence of oxygenated hydrocarbons such as sesquiterpenoids and monoterpenoids in their composition which are well-known as potent antioxidants and able to trap the chain-carrying lipid peroxyl radicals responsible for lipid oxidation. Recently, it has been reported that other simple components of EOs including terpenoids may potentially contribute to the scavenging of the harmful free radicals [5].

De facto, many studies reported that the mechanism of action of the EOs as antiobesity agents may be attributed to several possible factors such as their ability to suppress the effect of pancreatic lipase enzyme, increase the glycerol level in the plasma, or inhibit the accumulation of fats in the human body [6,7].

Recently, diabetes is recognized as a global problem, with the number of diabetics rising in 1980 from 200 million to 420 million in 2014. In the previous two years, it was the leading cause of million deaths worldwide, according to $\mathrm{WHO}$, it was ranked as the seventh leading cause of death [8-10].

Several in vivo and in vitro investigations proved that the natural plants' EOs reduced blood glucose levels by improving the distorted pancreatic $\beta$-cells architecture of diabetic animals or by inactivation of enzymes such as $\alpha$-glucosidase and $\alpha$-amylase that are responsible for the metabolism of carbohydrates in the gastrointestinal tract. Overall, the antidiabetic effect of the EOs may prove to be of clinical value in the treatment of hyperglycemia [11-14].

Natural plant EOs have been reported to possess antiproliferative, antioxidant, antimutagenic, and detoxifying activities, as well as they, have cancer preventative properties. In addition, EOs can increase the efficacy of many chemotherapeutic agents such as docetaxel and paclitaxel also may improve the immune system function for patients suffering from cancer. However, several investigations revealed that EOs have anticancer activity throughout several mechanisms of actions including that they can slow cancer cell division by interfering with the cell cycle, induce apoptosis, inhibit phase 1 enzymes that convert harmless compounds into carcinogens, and induce phase 2 enzymes that can attach carcinogens to compounds that facilitate speedy excretion [15].

Actually, EOs inhibit or slow the microbial growth through a variety of targets, including their ability to destroy the microbial cells membrane s and cytoplasm, and in some cases, EOs can change the morphology of some microbial species [16].

Recently, due to the extreme negative cardiovascular and gastrointestinal effects of nonsteroidal anti-inflammatory drugs (NSAIDs) and selective COX-2 inhibitors, researchers are looking for more potential anti-inflammatory agents with fewer adverse effects than NSAIDs [17]. As a result, EOs are now seen as promising targets for the next wave of antiinflammatory treatments as well as they can inhibit transcription of NF- $\mathrm{KB}$ and suppress the cascade of arachidonic acid $[18,19]$.

In folk medicine all over the world, Artemisia species are widely utilized as antioxidant, antifungal, antimalarial, insecticidal, antimicrobial, antispasmodic, antitumor, and anti-inflammatory activities [20].

Artemisia jordanica Danin (AJ); is a perennial aromatic herbaceous shrubby plant that belongs to the Compositae family with succulent, narrow, and simple leaves. Its native range is South Palestine to Iraq. The leaves decoction of (AJ) plant is utilized in traditional Bedouin medicine as an antihypertensive, antispasmodic, and anthelmintic medicine [21].

As far as I know, no investigation has yet identified the chemical components and examined the biological effects of EOs obtained from the (AJ) aromatic plant. The present work aims to identify and quantify the chemical ingredients of (AJ) EO for the first time 
and evaluate its antioxidant, anti-obesity, antidiabetic, antimicrobial, anti-inflammatory, and cytotoxic activities.

\section{Results}

\subsection{Phytochemistry}

The chemical constituents of the (AJ) EO were investigated by gas chromatographymass spectrometry (GC-MS) analysis (Figure 1). Nineteen compounds were qualitatively and quantitatively characterized in the EO of the (AJ) leaves, representing $100 \%$ of the total EO mass, as presented in Table 1, where bornyl acetate (63.40\%) and endo-borneol (17.75\%) were identified as the abundant ingredients. Moreover, the major phytochemical classes were oxygenated monoterpenoids $(85.98 \%)$ and oxygenated sesquiterpenoid $(8.01 \%)$.

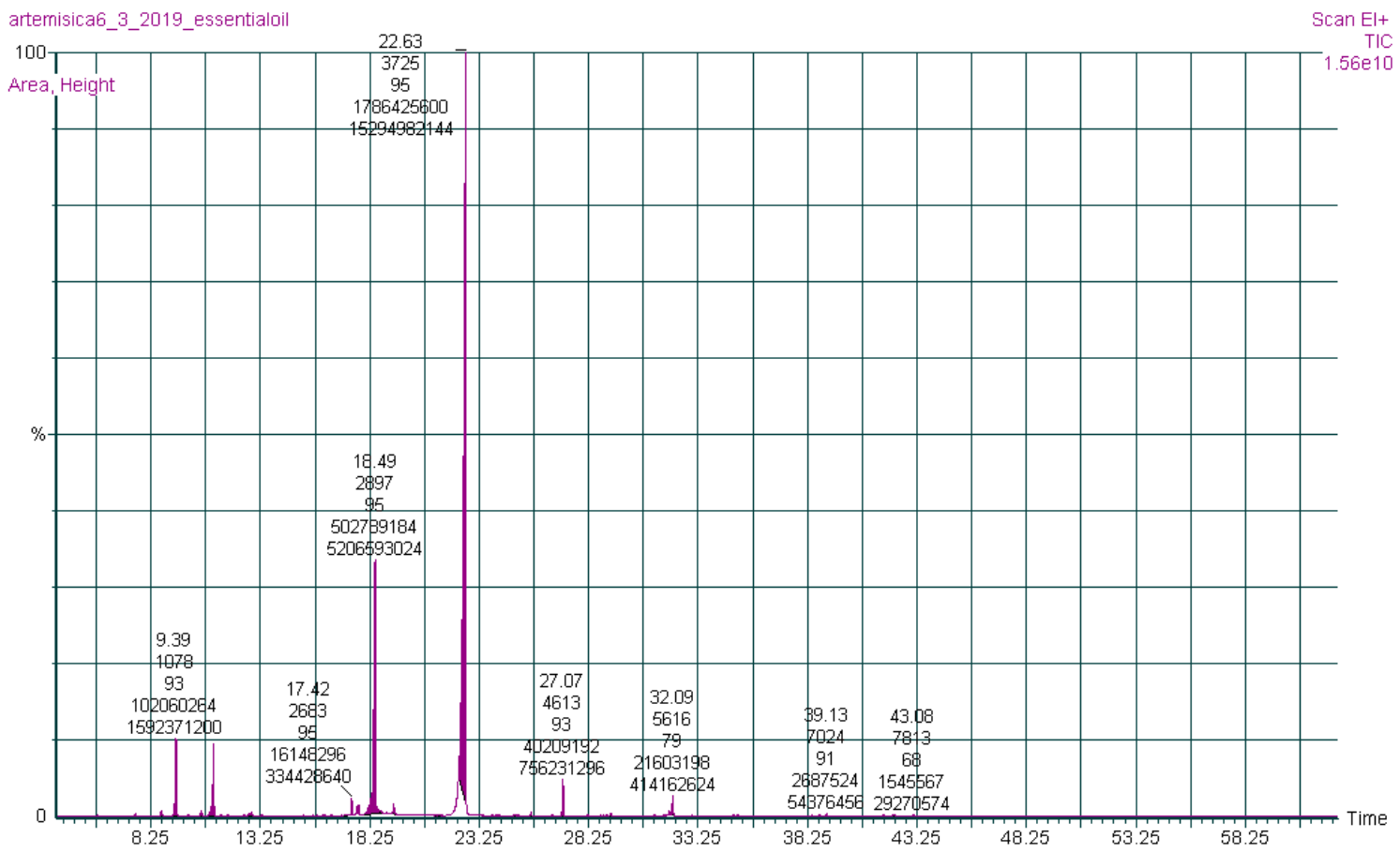

Figure 1. Gas chromatography-mass spectrometry chromatograph of Artemisia jordanica essential oil.

Table 1. The chemical ingredients of Artemisia jordanica essential oil.

\begin{tabular}{cccc}
\hline Name & $\begin{array}{c}\text { Retention } \\
\text { Index }_{\text {calculated }}\end{array}$ & $\begin{array}{c}\text { Retention } \\
\text { Index } \text { Litreture }_{\text {[22] }}\end{array}$ & $\begin{array}{c}\text { Essential Oil } \\
\mathbf{( \% )}\end{array}$ \\
\hline Thujene & 912 & 911 & 0.13 \\
a-Pinene & 936 & 936 & 0.28 \\
Camphene & 953 & 954 & 3.62 \\
Sabinene & 979 & 979 & 0.26 \\
2,3-Dehydro-1,8-Cineole & 991 & 991 & 3.56 \\
Cineole & 1040 & 1041 & 0.20 \\
Camphor & 1142 & 1141 & 0.57 \\
Nirol oxide & 1161 & 1160 & 0.23 \\
Terpinen-4-ol & 1163 & 1162 & 0.27 \\
Endo-borneol & 1178 & 1178 & 17.75 \\
Bornyl acetate & 1280 & 1280 & 63.40 \\
Caryophyllene & 1420 & 1421 & 1.43 \\
Germacrene & 1489 & 1489 & 0.14 \\
Caryophyllene oxide & 1574 & 1574 & 0.14 \\
\hline
\end{tabular}


Table 1. Cont.

\begin{tabular}{|c|c|c|c|}
\hline Name & $\begin{array}{c}\text { Retention } \\
\text { Index } \\
\text { calculated }\end{array}$ & $\begin{array}{c}\text { Retention } \\
\text { Index }_{\text {Litreture }}[22]\end{array}$ & $\begin{array}{c}\text { Essential Oil } \\
(\%)\end{array}$ \\
\hline Geranyl isovalerate & 1602 & 1602 & 7.67 \\
\hline 14-Hydroxy-(Z)-caryophelene & 1667 & 1667 & 0.07 \\
\hline Germacra-4(15),5,10(14)-trien- $1 \alpha$-ol & 1674 & 1674 & 0.14 \\
\hline Farnesyl & 1803 & 1803 & 0.10 \\
\hline \multicolumn{4}{|c|}{ Phytochemical Classes } \\
\hline Monoterpene hydrocarbon & & & 4.28 \\
\hline Oxygenated monoterpenoid & & & 85.98 \\
\hline Sesquiterpene hydrocarbon & & & 1.66 \\
\hline Oxygenated sesquiterpenoid & & & 8.01 \\
\hline
\end{tabular}

\subsection{Antioxidant Activity}

In this study, the (AJ) EO showed a dose-dependent inhibitory activity against DPPH free radical activity and has $74.88 \%$ of the antioxidant potential compared with a standard antioxidant compound Trolox. The DPPH inhibitory activity by (AJ) EO and Trolox is shown in Figure 2 and the $\mathrm{IC}_{50}$ values are presented in Table 2.

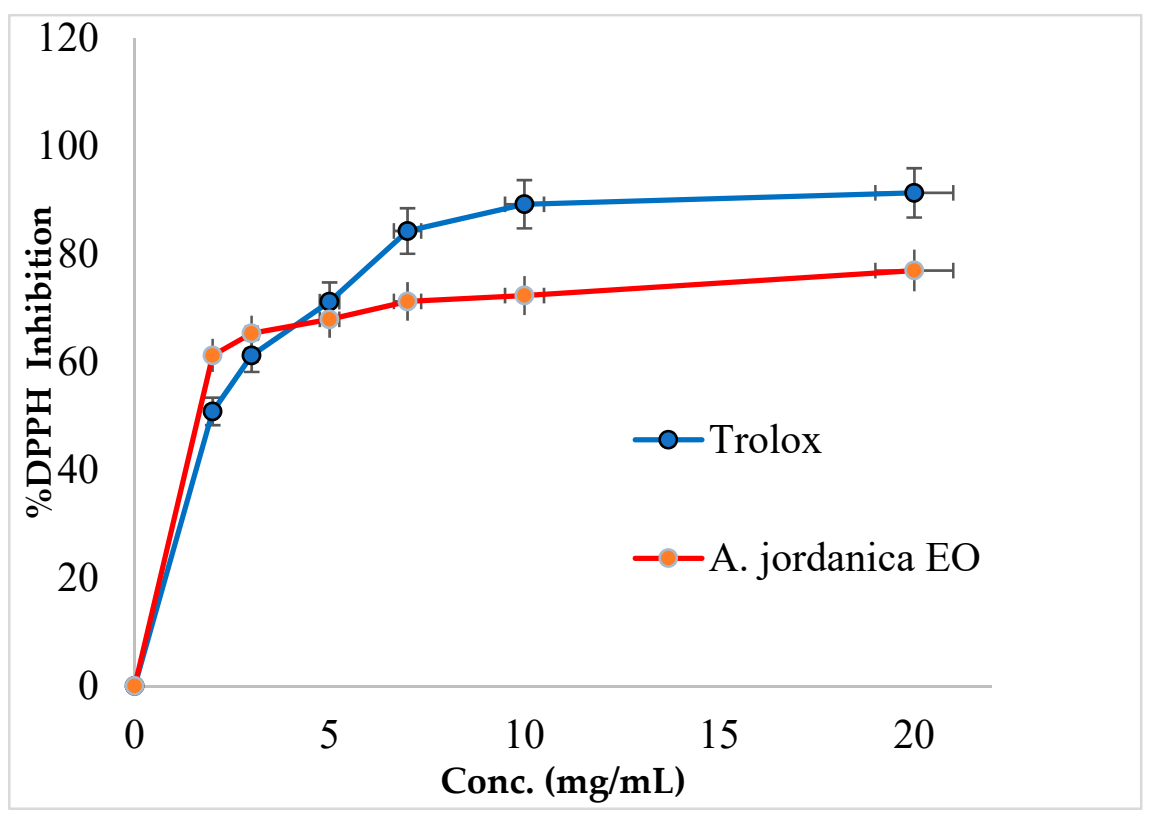

Figure 2. DPPH inhibitory activity by Artemisia jordanica essential oil and Trolox.

Table 2. The $\mathrm{IC}_{50}(\mu \mathrm{g} / \mathrm{mL})$ for Artemisia jordanica essential oil against DPPH, lipase, $\alpha$-amylase, $\alpha$-glucosidase, and cancer cells in comparison with the positive controls.

\begin{tabular}{|c|c|c|}
\hline \multirow{2}{*}{$\begin{array}{l}\text { Antioxidant, Target } \\
\text { Metabolic Enzymes, and } \\
\text { Cancer Cells Lines }\end{array}$} & \multicolumn{2}{|c|}{$\mathrm{IC}_{50}(\mu \mathrm{g} / \mathrm{mL})$} \\
\hline & $\begin{array}{c}\text { Artemisia jordanica } \\
\text { Essential Oil }\end{array}$ & Positive Controls \\
\hline DPPH & $2.18 \pm 0.24$ & $1.58 \pm 1.49^{a}$ \\
\hline Lipase & $51.41 \pm 0.91$ & $0.13 \pm 0.86^{b}$ \\
\hline$\alpha$-Amylase & $14.17 \pm 0.39$ & $8.53 \pm 0.72^{c}$ \\
\hline$\alpha$-Glucosidase & $144.45 \pm 0.88$ & $62.36 \pm 1.05^{c}$ \\
\hline Caco-2 & $379.12 \pm 1.98$ & $0.37 \pm 0.08^{\mathrm{d}}$ \\
\hline HeLa & $15412 \pm 2.2$ & $0.84 \pm 0.03^{d}$ \\
\hline MCF7 & $2550 \pm 2.11$ & $0.43 \pm 0.06^{\mathrm{d}}$ \\
\hline HepG2 & $440.12 \pm 3.11$ & $1.21 \pm 0.05^{\mathrm{d}}$ \\
\hline
\end{tabular}

${ }^{\mathrm{a}}$ trolox; ${ }^{\mathrm{b}}$ orlistat; ${ }^{\mathrm{c}}$ acarbose; ${ }^{\mathrm{d}}$ doxorubicin. 


\subsection{Target Metabolic Enzyme Inhibitory Activity}

The EO of the (AJ) plant showed dose-dependent inhibitory activity against porcine pancreatic lipase, $\alpha$-amylase, and $\alpha$-glucosidase, compared with the positive controls, which were the anti-obesity drug orlistat and the antidiabetic medication acarbose. The results arising from the lipase, $\alpha$-amylase, and $\alpha$-glucosidase inhibitory activities evaluations of the (AJ) EO are shown in Figures 3-5, while the $\mathrm{IC}_{50}$ values are given in Table 2.

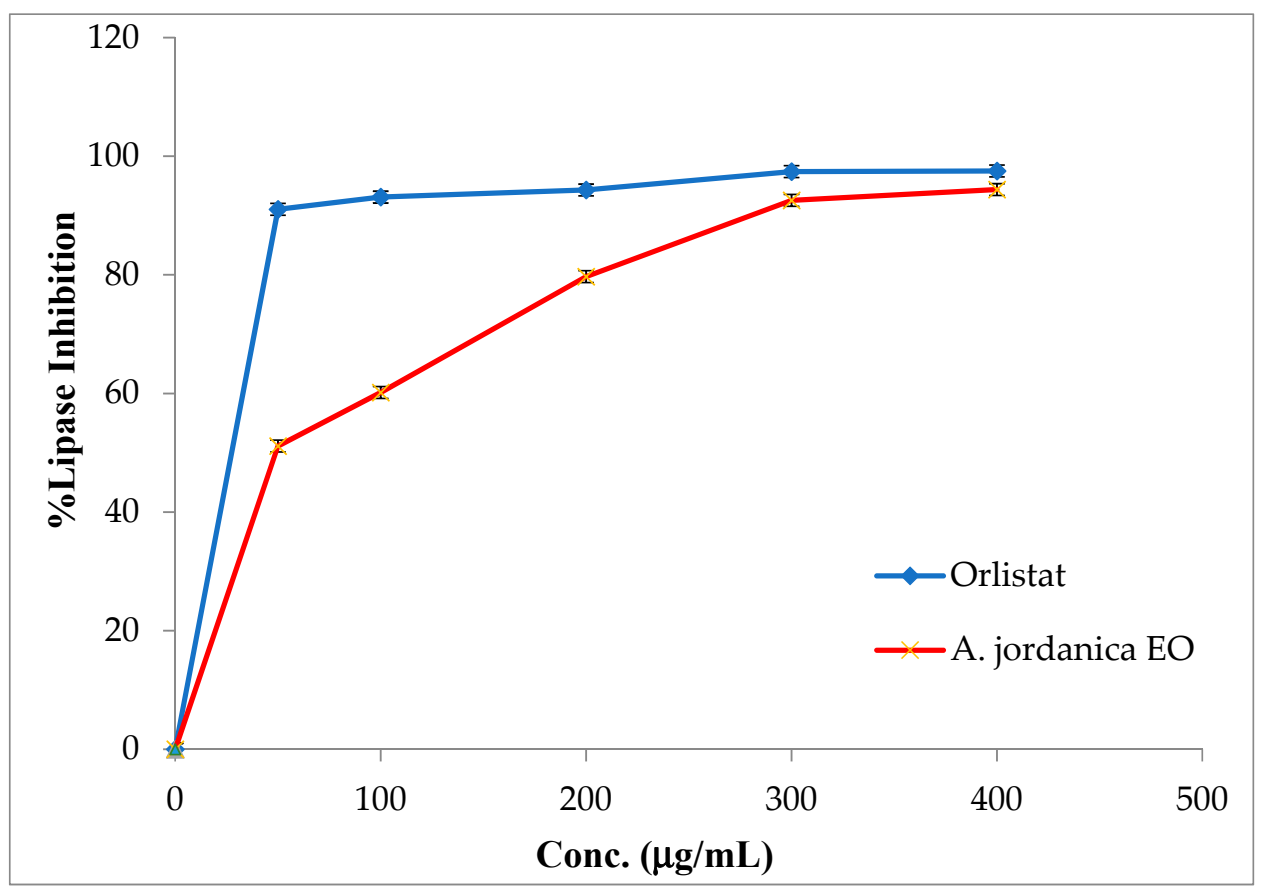

Figure 3. Porcine pancreatic lipase inhibitory activity by Artemisia jordanica essential oil and orlistat.

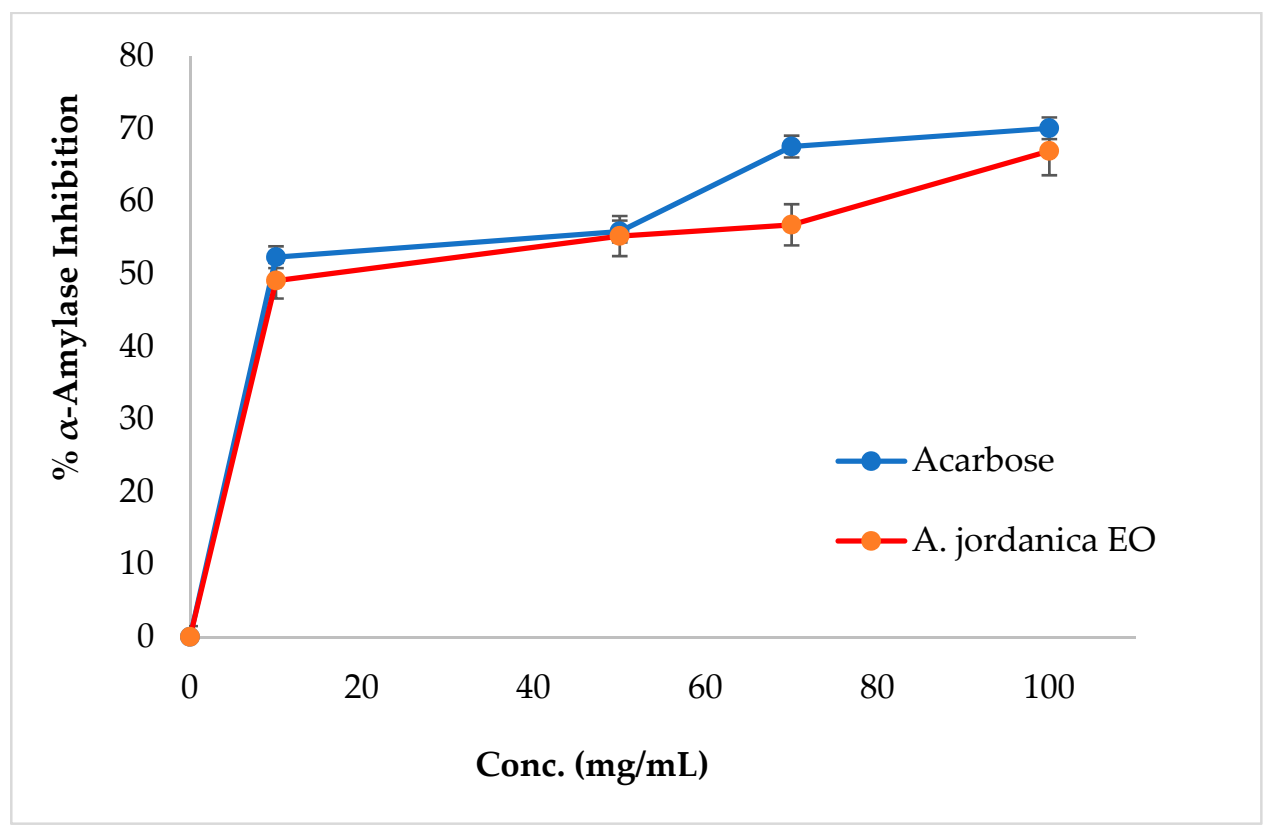

Figure 4. $\alpha$-Amylase inhibitory activity by Artemisia jordanica essential oil and acarbose. 


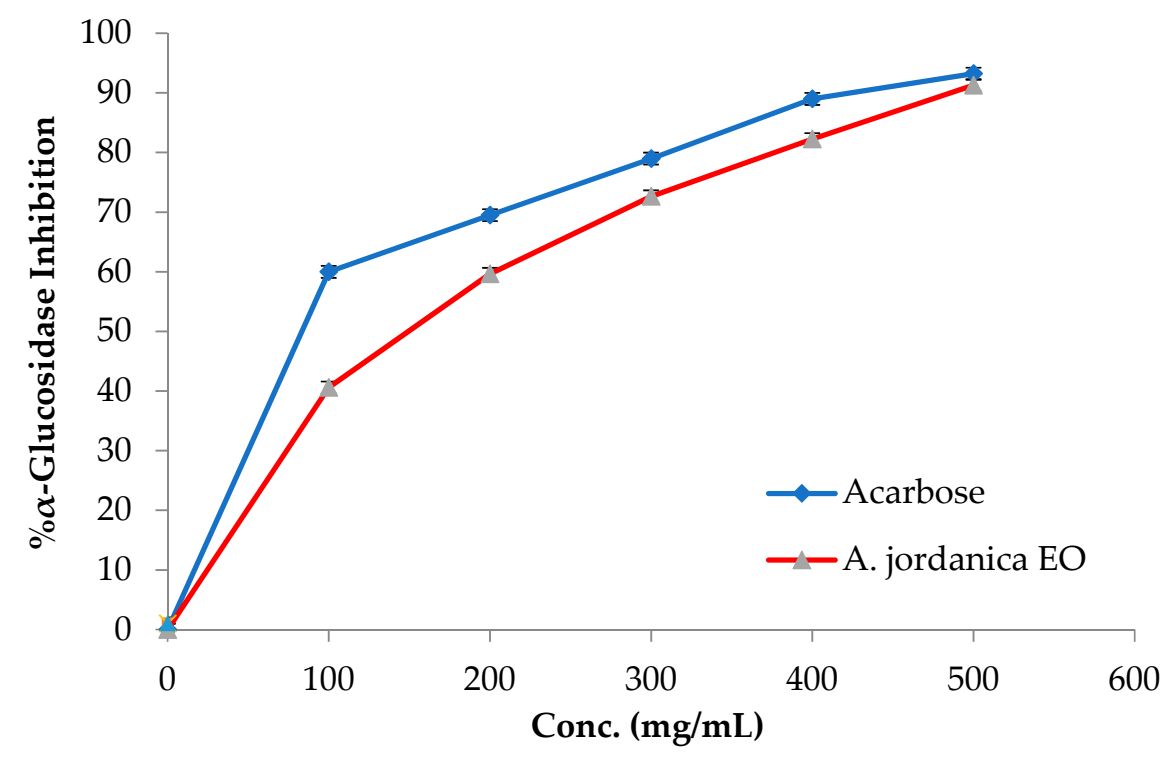

Figure 5. $\alpha$-Glucosidase inhibitory activity by Artemisia jordanica essential oil and acarbose.

\subsection{Cytotoxicity}

After treatment of HeLa, MCF-7, Caco-2, and Hep3B tumor cells with five different concentrations of (AJ) EO, the MTS assay results showed that the EO has cytotoxic activity against all the screened tumor cells as presented in Table 2. However, the cell viability percentage of the AJ EOs was calculated against all cancer cell at concentration $1 \mathrm{mg} / \mathrm{mL}$ and presented in Figure 6. It was clear that the EOs has potent cytotoxic activities against Caco-2 and hepG2 with cell viability percentage $11.33 \%$ and $19.19 \%$, respectively. In contrast the cell viability percentage was high at this concentration against HeLa and MCF-7.

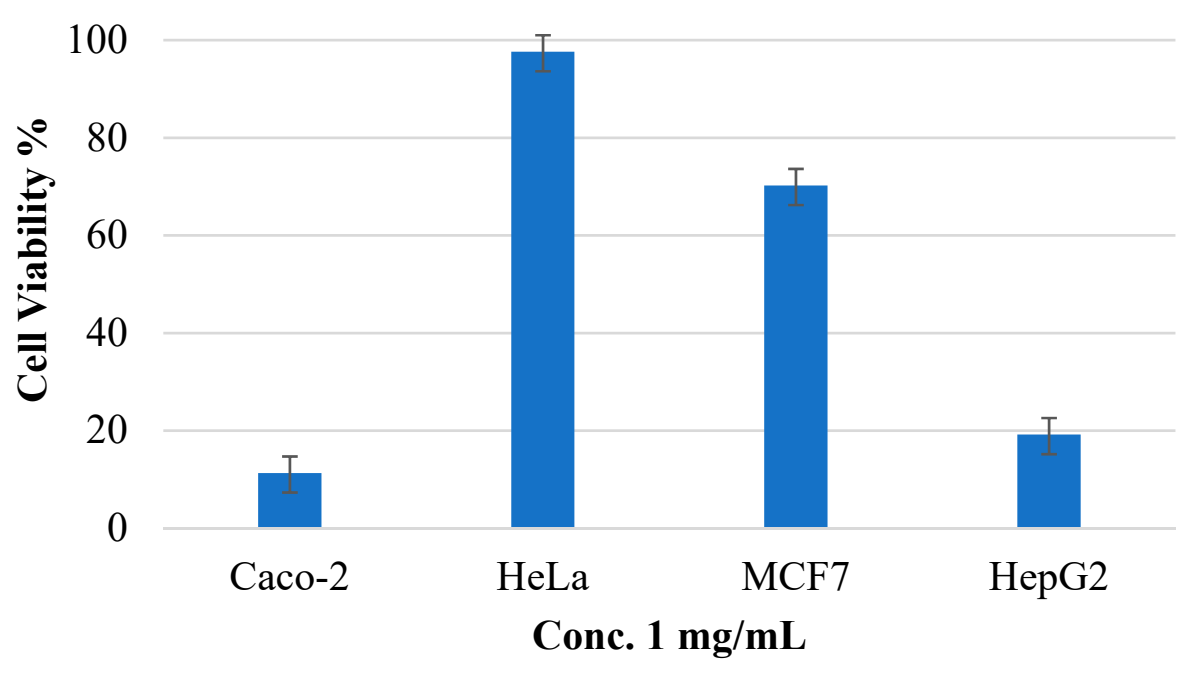

Figure 6. The cell viability percentage of Artemisia jordanica essential oil against four cancer cell lines at $1 \mathrm{mg} / \mathrm{mL}$ concentration $\pm \mathrm{SD}$.

\subsection{Antimicrobial Effect}

The antimicrobial activity of (AJ) EO was established using the broth microdilution method. The (AJ) EO inhibited the growth of most of the tested microbial strains. Table 3 depicts that (AJ) EO has remarkable antimicrobial effects against MRSA, S. aureus, $P$. vulgaris, and C. albicans compared with the positive antimicrobial controls, the commercial 
antibiotics ciprofloxacin and ampicillin, and commercial antifungal drug fluconazole, while the P. aeruginosa and E. coli strains were resistant to (AJ) EO.

Table 3. MIC values ( $\mu \mathrm{g} / \mathrm{mL}$ ) of Artemisia jordanica essential oil, ampicillin, ciprofloxacin and fluconazole.

\begin{tabular}{|c|c|c|c|c|c|c|c|}
\hline \multirow{2}{*}{ Tested Samples } & \multicolumn{7}{|c|}{ Microbial Strains } \\
\hline & MRSA & S. aureus & E. coli & K. pneumoniae & P. vulgaris & P. aeruginosa & C. albicans \\
\hline Fluconazole & - & - & - & - & - & - & 1.56 \\
\hline Ampicillin & $\mathrm{R}$ & 3.12 & 3.12 & 1 & 18 & $\mathrm{R}$ & - \\
\hline Ciprofloxacin & 12.5 & 0.78 & 1.56 & 0.125 & 15 & 3.12 & - \\
\hline $\begin{array}{l}\text { Artemisia jordanica } \\
\text { essential oil }\end{array}$ & 0.625 & 0.625 & $\mathrm{R}$ & 2.5 & 0.625 & $\mathrm{R}$ & 0.156 \\
\hline
\end{tabular}

R: Resistant.

\subsection{COX Inhibitory Activity}

The (AJ) EO was evaluated against COX enzymes, and its activity was compared with the positive control, the commercial NSAID Ketoprofen. In two concentrations 50 and $350 \mu \mathrm{g} / \mathrm{mL}$, the percentage inhibition of COX-1 and COX-2 increased with an increase in the concentration of EO used as presented in Figure 7. The (AJ) EO showed potential inhibitory activity towards COX-1 and COX-2 enzymes as presented in Table 4.

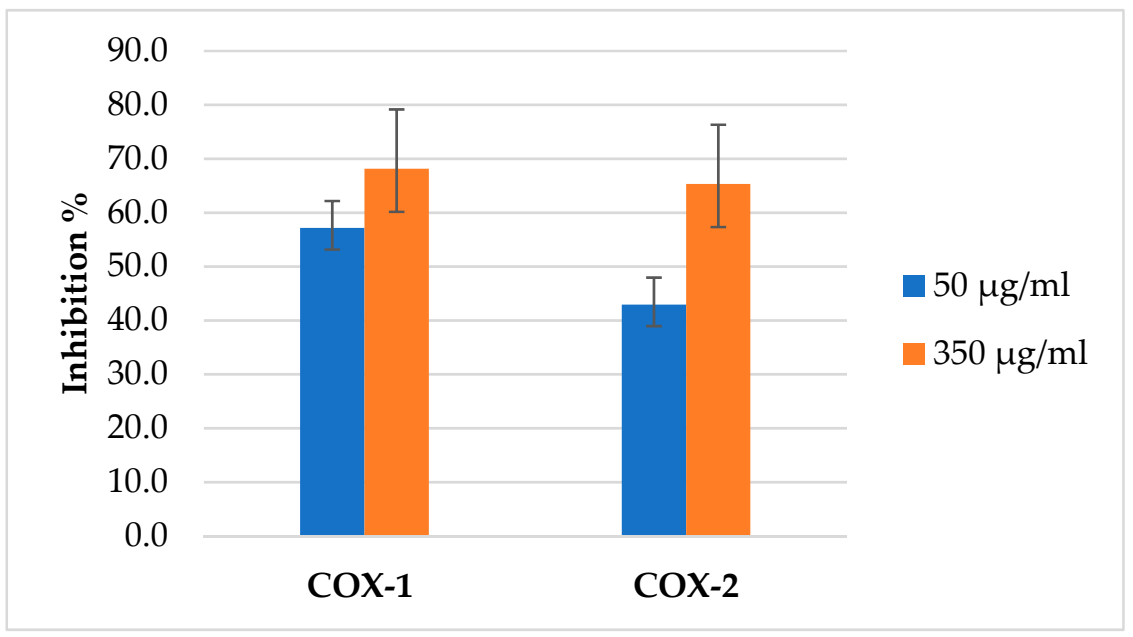

Figure 7. The inhibition percentage of Artemisia jordanica essential oil against COX1 and COX2 at two different concentrations 50 and $350 \mu \mathrm{g} / \mathrm{mL} \pm \mathrm{SD}$.

Table 4. IC $_{50}$ values of COX-1 and COX-2 and COX-2 inhibition selectivity of Artemisia jordanica essential oil.

\begin{tabular}{cccc}
\hline \multirow{2}{*}{ Name } & \multicolumn{2}{c}{ IC $_{\mathbf{5 0}}(\mu \mathrm{g} / \mathrm{mL})$} & \multirow{2}{*}{$\begin{array}{c}\text { Selectivity Ratio } \\
\text { for COX-2 }\end{array}$} \\
\cline { 2 - 3 } & COX-1 & COX-2 & \\
\hline Ketoprofen & $7.89 \pm 0.96$ & $40.18 \pm 1.09$ & 0.196 \\
Artemisia jordanica essential oil & $15.64 \pm 0.67$ & $91.91 \pm 1.91$ & 0.170 \\
\hline
\end{tabular}

\section{Discussion}

Since the beginning of history, medicinal herbal products were a valuable gift from nature for the treatment and prophylaxis of lethal diseases to humankind and animals. One hundred years ago, a simple wound could cause gangrenous and death, but now such as this infection can be treated quickly with an antibiotic ointment such as fusidic acid. Therefore, scientists must not lose the hope of discovering effective treatments for incurable diseases such as cancer, Alzheimer's, diabetes, hypertension, and many others. 
In nature, one of the main roles of the plants' secondary metabolites including EOs is a protection function against bacterial, viral, fungal, insects, and herbivore animal attacks. They are also able to attract certain kinds of insects for the pollination process. Thereby, EOs can play potential antimicrobial activity against various infectious diseases, flavoring agents in food industries, and main ingredients in cosmetics and perfumes [23]. The presence of heteroatomic compounds in the EOs can induce various biological activities such as antioxidant activity. In addition, oxygen-containing moieties such as oxygenated monoterpenoids and sesquiterpenoids have antioxidant activity more potent than nitrogencontaining structures such as aniline [24]. However, bornyl acetate as the main component of this EO may induce different pharmacological activities such as antioxidant and enzyme inhibitory activities. Among the EO compounds, the aromatic containing compounds such as camphene, sabinene, 2,3-dehydro-1,8-cineole, cineole, camphor, and nirol oxide have interesting antimicrobial activities as well as the aliphatic components, such as geranyl isovalerate, and Terpinen-4-ol showed potent antibacterial activities [25]. The oxygenated terpenoid compounds in high percentage of (AJ) EO such as endo-borneol and bornyl acetate have a high ability to penetrate the lipophilic lipids of the mitochondria and cytoplasmic membrane as well as they could disturb the structures and resulting in leakage of bacterial cell contents.

\subsection{Phytochemical Constituents}

The chemical ingredients of EOs depend on the plant's species, climatic conditions, origin, and seasonal variations. The phytochemical composition of (AJ) EO was identified and quantified utilizing GC-MS; 19 molecules were identified in the screened EO, representing $100 \%$ of the total mass. The results revealed that (AJ) EO is mainly composed of oxygenated monoterpenoid, monoterpene hydrocarbon, sesquiterpene hydrocarbon, and oxygenated sesquiterpenoid phytochemical classes which accounted for $85.98 \%, 4.28 \%$, $1.66 \%$, and $8.01 \%$, respectively. The major identified components were bornyl acetate $(63.40 \%)$, endo-borneol (17.75\%), and geranyl isovalerate $(7.67 \%)$.

The current investigation characterized for the first time the compositions of (AJ) EO and found that the abundant molecule bornyl acetate which also was the major component of Artemisia absinthium L. EO from Cuba and presented 23.02\% of the identified components [26].

However, bornyl acetate was one of the constituents but not the major one of various Artemisia species including A. herba [27], A. frigida, A. argyrophylla [28], A. selengensis [20], and A. dracunculus [29].

\subsection{Antioxidant Activity}

The in vitro DPPH free radical scavenging assay is intended to mimic the oxidationreduction reactions that usually occur in living organisms, and it was utilized to evaluate the antioxidant properties of various kinds of biological and chemical samples. Regarding the antioxidant activity, the (AJ) EO was able to reduce DPPH radicals into the natural DPPH$\mathrm{H}$ form, and this effect occurred in a dose-dependent manner. In fact, (AJ) EO exhibited potent antioxidant activity, with an $\mathrm{IC}_{50}$ value of $2.18 \pm 0.24 \mu \mathrm{g} / \mathrm{mL}$ and $74.88 \%$ antioxidant potential compared with Trolox, which has an antioxidant $\mathrm{IC}_{50}$ dose of $1.58 \pm 1.49 \mu \mathrm{g} / \mathrm{mL}$. In fact, Trolox is a vitamin $\mathrm{E}$ analog with powerful antioxidant properties, and it is used in different biochemical or biological applications to prevent the production of harmful free radicals and to decrease the damage caused by oxidative stress.

A study conducted by Juteau et al. found that the EO extracted from A. annua had an antioxidant activity equivalent to $18 \%$ of the positive control ( $\alpha$-tocopherol) [30].

Several studies have estimated the antioxidant character of the Artemisia genus EO from different species, and the current study of the (AJ) EO showed the strongest antioxidant potential compared with these studies [30-33].

The antioxidant character of (AJ) EO may be attributed to the presence of a high percentage of bornyl acetate which also showed potential antioxidant activity in several 
published works and approved that it has the potentials to scavenge free radicals and reduce oxidative stress [34-36].

\subsection{Metabolic Lipase, $\alpha$-Amylase, and $\alpha$-Glucosidase Inhibitory Activities}

Obesity, overweightness, diabetes, and dyslipidemia are global health problems with increasing prevalence [37]. Many scientific reports have found that they are directly associated with an increase in mortality rates of cancer and cardiovascular, respiratory, hepatic, and renal diseases [38]. In the last three decades, in Palestine and many other countries, the high prevalence of these metabolic disorders has been obvious and worrisome [39]. In fact, any pharmacological agent that can inhibit the actions of the vital metabolic enzymes, including lipase, $\alpha$-amylase, and $\alpha$-glucosidase, can inevitably cure these life-threatening disorders [40]. Actually, in various ethnopharmacological global systems of medicine, aromatic plants have long been utilized for the treatment of obesity, overweightness, dyslipidemia, and diabetes [41,42].

In the current study, the results showed that the (AJ) EO exhibited weak lipase inhibitory potential at the tested concentrations of $50,100,200,300$, and $400 \mu \mathrm{g} / \mathrm{mL}$, with inhibition in a dose-dependent manner and an $\mathrm{IC}_{50}$ value of $51.41 \pm 0.91 \mu \mathrm{g} / \mathrm{mL}$; although, the anti-lipase $\mathrm{IC}_{50}$ potential of the positive control (orlistat) was $0.13 \pm 0.86 \mu \mathrm{g} / \mathrm{mL}$.

Among many ethnomedicinal plants, many Artemisia species are traditionally utilized for the treatment of diabetes in several folk medicine systems $[43,44]$. Therefore, the current investigation was focused on assessing the ability of the (AJ) EO to inhibit the target carbohydrate metabolic enzyme inhibitors, including $\alpha$-amylase and $\alpha$-glucosidase. The results showed that the tested EO exhibited $\alpha$-amylase suppressing effect compared with the positive control, acarbose, with $\mathrm{IC}_{50}$ values of $14.17 \pm 0.39$ and $8.53 \pm 0.72 \mu \mathrm{g} / \mathrm{mL}$, respectively, at the tested concentrations $(10,50,70,100$, and $500 \mu \mathrm{g} / \mathrm{mL})$. Notably, the (AJ) EO exhibited strong $\alpha$-glucosidase inhibitory potential at the tested concentrations $(100,200,300,400$, and $500 \mathrm{mg} / \mathrm{mL})$, with inhibition in a concentration-dependent manner, compared with the positive control, acarbose, with $\mathrm{IC}_{50}$ values of $144.45 \pm 0.88$ and $62.36 \pm 1.05 \mu \mathrm{g} / \mathrm{mL}$, respectively.

Olennikov et al. investigated the $\alpha$-amylase and $\alpha$-glucosidase inhibitory activities of 12 Artemisia species which included A. umbrosa, A. tanacetifolia, A. sericea, A. palustris, A. messerschmidtiana, A. macrocephala, A. leucophylla, A. latifolia, A. integrifolia, A. desertorum, A. commutata, and A. anethifolia and found that these species had an $\alpha$-glucosidase inhibitory activity with $\mathrm{IC}_{50}$ range $214.42-754.12 \mu \mathrm{g} / \mathrm{mL}$ and $\alpha$-amylase suppressant potential with $\mathrm{IC}_{50}$ range of $150.24-384.14 \mu \mathrm{g} / \mathrm{mL}$ ) [45].

The current study is the first investigation that has assessed the inhibitory characteristics of the (AJ) EOs against lipase, $\alpha$-amylase, and $\alpha$-glucosidase.

\subsection{Cytotoxicity}

To understand the effect of the (AJ) EO on human cancer cells, the current investigation was carried out utilizing cultured HeLa, Caco-2, MCF-7, and Hep3B tumor cell lines. Viability results were measured using the trypan blue MTS assay. The results revealed that incubation of tumor cells with the (AJ) EO (1.25, 0.625, 0.3125, 0.15625, and $0.078125 \mathrm{mg} / \mathrm{mL}$ ) for $24 \mathrm{~h}$ reduced the viability of these cells in a dose-dependent manner. The number of dead cells increased by increasing the concentration of the (AJ) EO. The highest cytotoxic effect was observed against MCF-7 followed by Caco-2, Hep3B and HeLa cancer cells, with $\mathrm{IC}_{50}$ values of $255 \pm 2.11,379.12 \pm 1.98,440.12 \pm 3.11$ and $15,412 \pm 2.2 \mu \mathrm{g} / \mathrm{mL}$, respectively, compared with the potential anticancer drug doxorubicin (positive control), which had cytotoxic $\mathrm{IC}_{50}$ values of $0.43 \pm 0.06,0.37 \pm 0.08,1.21 \pm 0.05$, and $0.84 \pm 0.03 \mu \mathrm{g} / \mathrm{mL}$, respectively.

Bornyl acetate the chief constituent in the current study had a cytotoxic effect compared with the cis-platin anticancer drug with $\mathrm{IC}_{50}$ values of 71.97 and 126.75 , respectively. 


\subsection{Antimicrobial Activity}

Microbial resistance has become one of the most major global challenges during the last two decades, referring primarily to the overuse or misuse of antibiotics. Every year, approximately 2 million people in the United States are infected with antibiotic-resistant bacteria. Microbial resistance kills 700,000 people every year around the world [46].

Many EO-bearing plants have been utilized for the treatment of many infectious illnesses since ancient times. Indeed, EOs played an essential role in the design of novel potential bacteriostatic and fungistatic drugs such as thymol, eugenol, caryophyllene, and many others [47].

The EO from the dried leaves of (AJ) showed potent antimicrobial properties with higher antibacterial activity against MRSA, S. aureus, and P. vulgaris, each showing a MIC of $0.625 \mu \mathrm{g} / \mathrm{mL}$ than the commercial antibiotic ciprofloxacin which has a MIC of 12.5, 0.78 , and $15 \mu \mathrm{g} / \mathrm{mL}$, respectively. The EO also showed more potent antibacterial activity than ampicillin which does not have antibacterial activity against MRSA and has weak antibacterial activity against the rest of the bacterial strains. Indeed, the EO did not show any inhibitory activity against the growth of $E$. coli and P. aeruginosa strains.

Interestingly, the (AJ) EO showed a ten-fold more potent antifungal activity against C. albicans than the commercial anticandidal drug fluconazole, with a MIC of 0.156 and $1.56 \mu \mathrm{g} / \mathrm{mL}$, respectively. There was no noticeable difference in sensitivity between Grampositive and Gram-negative bacteria, while it is understood that the Gram-negative bacteria are less susceptible to EOs due to the existence of hydrophilic lipopolysaccharides (LPS) in their outer membrane. LPS prevents various hydrophobic EO compounds from penetrating the membrane. Actually, EOs and their hydrophobic ingredients can destroy bacterial cell membranes by removing their lipid fraction, impairing the bacterial cell's ability to survive [48-50].

EOs from different Artemisia species are well documented for their antimicrobial activity and several investigations have reported that they displayed remarkable antibacterial and antifungal activities against several microbial strains [51-53].

The results of the present investigation revealed that (AJ) EO has potent antibacterial and antifungal potentials against certain strains of microbial species. Actually, bornyl acetate, the study's main molecule, has long been recognized as a potent antimicrobial agent, according to numerous published studies [36,54,55].

\subsection{Cyclooxygenase Inhibitory Activity}

Cyclooxygenase inhibitory activity is an important tool to control the inflammation process in the human body. In fact, inflammation is an important physiological response of autoimmune activation, infection, or cellular injury. The excess production of proinflammatory mediators may cause different kinds of severe and chronic inflammation that lead to several illnesses including atherosclerosis, multiple sclerosis, asthma, arthritis, and rheumatoid arthritis [56].

The (AJ) EO COX inhibition activity test showed that the EO has more selective inhibition towards COX-1. Its COX-2 selectivity value hence was lower (0.17) and comparable to that of ketoprofen (0.196). The percentage inhibition of COX-2 increased with an increase in the concentration of EO used. When the EO concentration was increased from 50 to $350 \mu \mathrm{g} / \mathrm{mL}$, inhibition increased from $42.9 \%$ to $65.3 \%$. Similarly, COX-1 inhibition also increased with increasing $\mathrm{EO}$ concentration. Increasing the $\mathrm{EO}$ concentration from 50 to $350 \mu \mathrm{g} / \mathrm{mL}$ caused an increase in COX-1 inhibition from $57.2 \%$ to $68.2 \%$.

The current study results showed better inhibition activity of the extracted (AJ) EO as $50 \mu \mathrm{g} / \mathrm{mL}$ caused $57.2 \%$ and $42.5 \%$ inhibition of COX- 1 and COX-2, respectively. However, the (AJ) EO has more selectivity towards COX-1 hence its COX-2 inhibition selectivity $<1$ (0.017) compared with that of the commercial pharmaceutical preparation celecoxib [57]. The EO of (AJ) inhibited the enzymes COX-1 and COX-2 with IC 50 values of 15.64 and $91.91 \mu \mathrm{g} / \mathrm{mL}$, respectively, compared with the pharmaceutical anti-inflammatory drug ketoprofen which has an $\mathrm{IC}_{50}$ of 7.89 and $40.18 \mu \mathrm{g} / \mathrm{mL}$, respectively. 
Up to the knowledge of the authors, the current investigation represents the first phytochemical and biological experimental works carried out on the (AJ) plant EO and consequently, it might create the basis for more in vivo trials in search of eco-friendly green medications.

\section{Material and Methods}

\subsection{Collection and Drying of the Plant}

In July 2020, the leaves of the (AJ) plant were collected in Hebron's southern area, near Palestine's Al-Naqab desert. Dr. Nidal Jaradat, a pharmacognosist at An-Najah National University's Pharmacy Department, described the plant, and the voucher specimen was stored in the Herbal Products Laboratory (Pharm-PCT-237). The collected materials were cleaned and dried at ordinary room temperature $\left(25 \pm 4^{\circ} \mathrm{C}\right)$ and humidity $(50 \pm 6 \% \mathrm{RH})$ in the shade for 17 days. The dried leaves were then coarsely ground and kept in glass jars for further use.

\subsection{Isolation of Artemisia jordanica Essential Oil}

The EOs of the (AJ) plant were separated, utilizing the hydro-distillation procedure pronounced by Jaradat et al. [58]. Briefly, $0.1 \mathrm{~kg}$ of the dried leaf powder was suspended with $1 \mathrm{~L}$ of distilled water, and the EO was extracted at $100{ }^{\circ} \mathrm{C}$ using a Clevenger device (Deschem, Changshu, China) operating at atmospheric pressure for $180 \mathrm{~min}$. The obtained (AJ) EO was chemically dried utilizing calcium carbonate and stored at $2{ }^{\circ} \mathrm{C}$ in a refrigerator until further use. The extracted EO yield was $1.31 \% v / w$.

\subsection{Characterization of Artemisia jordanica Essential Oil}

The phytochemical profile of A (AJ) EO was determined utilizing a gas chromatograph (Hewlett Packard HP 5890 Series II, Houston, TX, USA) connected with mass spectrometry (PerkinElmer, Elite-5-MS, Massachusetts, United States) with a fused-silica capillary column ( $30 \mathrm{~m} \times 0.25 \mathrm{~mm}$, with a film thickness of $0.25 \mu \mathrm{m}$ ). at a flow rate of $1.1 \mathrm{~mL} / \mathrm{min}$, the helium gas was set while the injector temperature was fixed at $250^{\circ} \mathrm{C}$, the oven temperature was set at $50{ }^{\circ} \mathrm{C}$ for $5 \mathrm{~min}$ followed by a ramp of $4.0^{\circ} \mathrm{C} / \mathrm{min}$ to $280{ }^{\circ} \mathrm{C}$. The total running time was $62.50 \mathrm{~min}$, and the solvent delay was from 0 to $4.0 \mathrm{~min}$. The mass spectroscopy (MS) scan time was from 4 to $62.5 \mathrm{~min}$, covering a mass range of 50.00 to $300.00 \mathrm{~m} / \mathrm{z}$. The mass spectra were collected under electronic ionization conditions at $70 \mathrm{eV} \mathrm{[59].} \mathrm{In} \mathrm{brief,}$ retention indices (RIs) have been calculated according to the injected standard mixture of normal alkanes (C6-C27) under the mentioned conditions using the following well-known equation approved by the International Union of Pure and Applied Chemistry (IUPAC) (https:/ / goldbook.iupac.org/terms/view/R05360). The identification was also confirmed by comparison of their mass spectra with those stored in the Wiley7n.1 MS computer library. The linear temperature-programmed RIs of all the constituents were calculated from the gas chromatogram by interpolation between bracketing $n$-alkanes using the following equation:

$$
\mathrm{RI}=100 \times(((\mathrm{tR}(\mathrm{i})-\mathrm{tR}(\mathrm{z})) /(\mathrm{tR}(\mathrm{z}+1)-\mathrm{tR}(\mathrm{z})))+\mathrm{z})
$$

where $\mathrm{z}$ is the number of carbon atoms in the smaller $\mathrm{n}$-alkane and $\mathrm{tR}(\mathrm{i}), \mathrm{tR}(\mathrm{z})$, and $\mathrm{tR}(\mathrm{z}+1)$ are the retention times of the desired compound, the smaller n-alkane, and the larger n-alkane, respectively.

\subsection{Free Radical Scavenging Activity}

One hundred mg of (AJ) EO was dissolved in $100 \mathrm{~mL}$ of methanol to create the stock solution $(1 \mathrm{mg} / \mathrm{mL})$. The obtained solution was mixed with methanol to obtain different concentrations $(2,3,5,7,10,20,30,40,50,80$, and $100 \mu \mathrm{g} / \mathrm{mL})$. One milliliter of stock solution and $1 \mathrm{~mL}$ of methanol were mixed with $1 \mathrm{~mL}$ of DPPH (Sigma-Aldrich, Steinheim, Germany). Then, the solution was kept in the dark at room temperature for $30 \mathrm{~min}$. However, by replacing the plant EO solution with methanol, the blank solution was prepared. Trolox (Sigma-Aldrich, St. Louis, MO, USA) was utilized as a positive 
control, and the absorbance for all obtained samples was measured by spectrophotometer (Shimadzu-UV-1800, Kyoto, Japan) at $517 \mathrm{~nm}$. The DPPH inhibitory potentials were estimated utilizing the following formula:

$$
\left.\mathrm{I}(\%)=\left[\mathrm{ABS}_{\text {blank }}-\mathrm{ABS}_{\text {test }}\right] /\left[\mathrm{ABS}_{\text {blank }}\right]\right) \times 100 \%
$$

where I (\%) is the percentage of DPPH inhibitory potentials $[60,61]$.

\subsection{Porcine Pancreatic Lipase Inhibitory Activity}

A working solution ( $1 \mathrm{mg} / \mathrm{mL}$ ) was done by dissolving $100 \mathrm{mg}$ of the (AJ) EO in $100 \mathrm{~mL}$ of $10 \%$ dimethyl sulfoxide (DMSO) (Riedeldehan, Seelze, Germany). Then, the obtained solution was diluted to produce the following concentrations: 400, 300, 200, 100, and $50 \mu \mathrm{g} / \mathrm{mL}$. Porcine pancreatic lipase enzyme (Sigma, St. Louis,, MO, USA) stock solution $(1 \mathrm{mg} / \mathrm{mL})$ was directly prepared before use by dissolving $25 \mathrm{mg}$ of lipase enzyme powder in $25 \mathrm{~mL}$ of 10\% DMSO. Then, p-nitrophenyl butyrate (PNPB) (Sigma-Aldrich, Schnelldorf, Germany) stock solution was prepared by dissolving $20.9 \mathrm{mg}$ of $P$ NPB in $2 \mathrm{~mL}$ of acetonitrile. From the prepared serial dilutions of the (AJ) EO, $0.2 \mathrm{~mL}$ was mixed with $0.1 \mathrm{~mL}$ of the lipase enzyme stock solution and tris- $\mathrm{HCl}$ (Sigma, $\mathrm{MO}$, USA) to reach a volume of $1 \mathrm{~mL}$. Then, the solution was incubated for $15 \mathrm{~min}$ at $37^{\circ} \mathrm{C}$ in a water bath. After $15 \mathrm{~min}, 100 \mu \mathrm{L}$ of $P$ NPB solution was added, and the solution was incubated for $30 \mathrm{~min}$ at $37^{\circ} \mathrm{C}$. A $1 \mathrm{~mL}$ blank solution was prepared by mixing $100 \mu \mathrm{L}$ of lipase enzyme $(1 \mathrm{mg} / \mathrm{mL})$ solution with a tris- $\mathrm{HCl}$ solution. The commercial anti-obesity drug orlistat (Sigma-Aldrich, Schnelldorf, Germany) was utilized as a positive control, and we followed the same previous steps as the (AJ) EO. The absorbance was measured utilizing a UVVis-spectrophotometer at $405 \mathrm{~nm}$. However, the lipase enzyme inhibitory potential was measured utilizing the following equation:

$$
\left.\mathrm{I}(\%)=\left[\mathrm{ABS}_{\text {blank }}-\mathrm{ABS}_{\text {test }}\right] /\left[\mathrm{ABS}_{\text {blank }}\right]\right) \times 100 \%
$$

where I (\%) is the percent inhibition of the lipase enzyme [62].

\section{6. $\alpha$-Amylase Inhibitory Activity}

A stock solution ( $1 \mathrm{mg} / \mathrm{mL})$ was prepared by dissolving $25 \mathrm{mg}$ of the (AJ) EO in a small amount of $10 \%$ DMSO. Then, a buffer solution was added to $25 \mathrm{~mL}$. The solution was then diluted with the buffer to obtain different dilutions $(10,50,70,100$, and $500 \mu \mathrm{g} / \mathrm{mL})$. Later on, the porcine pancreatic $\alpha$-amylase enzyme (Sigma-Aldrich, USA) stock solution ( 2 units $/ \mathrm{mL}$ ) was made by mixing $12.5 \mathrm{mg}$ of $\alpha$-amylase powder with a minimum amount of $10 \%$ DMSO, and the volume was completed with a buffer solution to $100 \mathrm{~mL}$. Then, corn starch (Alzahraa company, Palestine) solution was prepared by dissolving $1 \mathrm{~g}$ of starch in $100 \mathrm{~mL}$ of distilled water. Two hundred microliters of the (AJ) EO stock solution were mixed with $200 \mu \mathrm{L}$ of the $\alpha$-amylase stock solution, and the solution was incubated for $10 \mathrm{~min}$ at $30^{\circ} \mathrm{C}$ in a water bath. After that, $200 \mu \mathrm{L}$ of corn starch solution was added and incubated for $3 \mathrm{~min}$ at $30^{\circ} \mathrm{C}$. Moreover, 3,5-dinitrosalicylic acid (Sigma, India) was added and boiled in a water bath at $85-90{ }^{\circ} \mathrm{C}$ for $10 \mathrm{~min}$, and after the solution was cooled, $5 \mathrm{~mL}$ of distilled water was added. The blank solution was prepared by replacing the (AJ) plant EO with $200 \mu \mathrm{L}$ of a buffer solution. Acarbose was used as a positive reference compound while the absorbance was assessed at $540 \mathrm{~nm}$ using a UV-Vis- spectrophotometer. The $\alpha$-amylase inhibitory potential was calculated by the following formula:

$$
\mathrm{I}(\%)=\left[\mathrm{ABS}_{\text {blank }}-\mathrm{ABS}_{\text {test }}\right] /\left[\mathrm{ABS}_{\text {blank }}\right] \times 100 \%
$$

where I (\%) is the $\alpha$-amylase inhibitory percentage $[63,64]$. 


\section{7. $\alpha$-Glucosidase Inhibitory Activity}

The $\alpha$-glucosidase inhibitory activity of the (AJ) EO was determined according to the standard protocol, with some modifications [40]. In each test tube, a reaction mixture containing $50 \mu \mathrm{L}$ of phosphate buffer $(100 \mathrm{mM}, \mathrm{pH}=6.8), 10 \mu \mathrm{L}$ of $\alpha$-glucosidase $(1 \mathrm{U} / \mathrm{mL})$, and $20 \mu \mathrm{L}$ of varying concentrations of (AJ) EO (100, 200, 300, 400, and $500 \mu \mathrm{g} / \mathrm{mL})$ was incubated at $37^{\circ} \mathrm{C}$ for $15 \mathrm{~min}$. Then, the preincubated $20 \mu \mathrm{L}$ of $(5 \mathrm{mM})$ PNPG (4Nitrophenyl- $\beta$-D-glucopyranoside) was added as a substrate of the reaction and was again incubated at $37{ }^{\circ} \mathrm{C}$ for an additional $20 \mathrm{~min}$. The reaction was terminated by adding $50 \mu \mathrm{L}$ of $\mathrm{Na}_{2} \mathrm{CO}_{3}(0.1 \mathrm{M})$. The absorbance of the released p-nitrophenol was measured by a UV-Vis spectrophotometer at $405 \mathrm{~nm}$. With similar concentrations as the plant EO, acarbose was used as a positive control.

The inhibition percentage of the (AJ) EO was calculated using the following equation:

$$
\alpha-\text { Glucosidase } \%=\frac{A_{b}-A_{s}}{A_{b}} \times 100
$$

where $A_{b}$ is the absorbance of the blank and $A_{S}$ is the absorbance of the tested sample or control.

\subsection{Cell Culture and Cytotoxicity Assay}

The liver (Hep3B), breast (MCF-7), Human cervical (HeLa), and Colon (CACO-2) tumor cell lines were cultivated separately in RPMI-1640 media (Sigma, Norwich, UK), which was treated with $1 \%$ L-glutamine (Sigma, London, UK), 1\% penicillin/streptomycin antibiotics (BI, New Delhi, India), and 10\% fetal bovine serum. Cancer cells were grown at $37^{\circ} \mathrm{C}$ in a humidified atmosphere with $5 \% \mathrm{CO}_{2}$. Cells were seeded at $2.6 \times 10^{4}$ cells/well in a 96-well plate. After $48 \mathrm{~h}$, cancer cells were incubated with various concentrations $(500,120,60,30$, and $10 \mu \mathrm{g} / \mathrm{mL}$ ) of the (AJ) EO and doxorubicin (positive control) for $24 \mathrm{~h}$. Cell viability was evaluated by the CellTilter $96^{\circledR}$ Aqueous One Solution Cell Proliferation (MTS) Assay according to the manufacturer's directions (Promega Corporation, Madison, WI, USA). At the end of the treatment, $20 \mu \mathrm{L}$ of MTS solution per $100 \mu \mathrm{L}$ of media was added to each well, and the solutions in the well plates were incubated at $37^{\circ} \mathrm{C}$ for $2 \mathrm{~h}$. The absorbance was measured at $490 \mathrm{~nm}[65,66]$.

\subsection{Microbial Strains, Culture Media, and Antimicrobial Assay}

The antibacterial effect of (AJ) EO was determined utilizing several strains of bacteria, which were obtained from the American Type Culture Collection (ATCC): Pseudomonas aeruginosa (ATCC 9027), Escherichia coli (ATCC 25922), Klebsiella pneumonia (ATCC 13883), Proteus vulgaris (ATCC 8427), and Staphylococcus aureus (ATCC 25923), and from a diagnostically confirmed methicillin-resistant Staphylococcus aureus (MRSA). The antifungal activity of (AJ) EO was evaluated against the growth of Candida albicans (ATCC 90028). The antimicrobial activity of the (AJ) EO used in this study was estimated using the broth microdilution method. The (AJ) EO was dissolved in DMSO to a concentration of $200 \mu \mathrm{g} / \mathrm{mL}$. The produced solution was serially micro-diluted (2-fold) 10 times in sterile Mueller-Hinton broth (Thermo Fisher Scientific, Waltham, MA, USA). The dilution processes were performed under aseptic conditions in 96-well plates. In the micro-wells that were assigned to evaluate the antibacterial activity of (AJ) EO, micro-well number 11 contained plant-free Mueller-Hinton broth, which was used as a positive control for microbial growth. Micro-well number 12 contained plant-free and microbial-free Mueller-Hinton broth, which was used as a negative control for microbial growth. Micro-wells numbered 1-11 were inoculated aseptically with the test microbes. The (AJ) EO antimicrobial activity was determined in triplicate. All the inoculated plates were incubated at $35^{\circ} \mathrm{C}$. Regarding C. albicans, the same method was used but using RPMI media (Thermo Fisher Scientific, Waltham, MA, USA) instead of Mueller-Hinton broth. The incubation period lasted for about 18-24 $\mathrm{h}$ for those plates inoculated with the test bacterial strains and for about $48 \mathrm{~h}$ for those plates inoculated with C. albicans. The lowest concentration of (AJ) EO 
at which no visible microbial growth was observed in the micro-well was considered as the minimum inhibitory concentration (MIC) of the examined EO. Antimicrobial activity was evaluated using known antimicrobial agents, namely ampicillin and ciprofloxacin, which were used as positive controls for antibacterial activity, and fluconazole, which was used as the positive control for antifungal activity $[67,68]$.

\subsection{COX Inhibitory Assay}

The ability of the (AJ) EO to prevent the conversion of arachidonic acid to PGH2 by bovine COX-1 and human recombinant COX-2 was assessed using a COX inhibitor screening assay kit (Item No: 560131, Cayman Chemical, Ann Arbor, MI, USA) according to manufacturer's guidelines. The $50 \%$ inhibitory concentration $\left(\mathrm{IC}_{50}\right)$ of COX-1/COX-2 activity of the tested samples was determined, with the assay run, in duplicate, with two concentrations ( 350 and $50 \mu \mathrm{g} / \mathrm{mL}$ ). A standard curve of eight concentrations of prostaglandin, a non-specific binding sample, and a maximum binding sample was used, as instructed in the kit manual, to determine the inhibition of the sample plant, applying the generated multiple regression best-fit line. The percentage inhibition of the two concentrations was used to calculate the $\mathrm{IC}_{50}[69,70]$.

\subsection{Statistical Analysis}

All of the (AJ) EO's antioxidant, antimicrobial, antilipase, cytotoxicity, COX, -amylase, and -glucosidase assays were carried out in triplicate, and the results were presented as means $\pm \mathrm{SD}$. Differences were considered to be significant when $\mathrm{p}$ values were lower than 0.05. The SPSS program, Version 22.0 for Windows was used for all statistical analyses (IBM SPSS Inc., Chicago, IL, USA).

\section{Conclusions}

Overall, the current investigation is the first one that explored the chemical constituents, antioxidant, antimicrobial, vital physiological enzymes inhibitory and cytotoxic effects of (AJ) EO. The results revealed that oxygenated terpenoids including bornyl acetate and endo-borneol presented are the major components of the (AJ) EO. Compared with the used positive controls, the (AJ) EO has strong antioxidant, antibacterial, antifungal, anti- $\alpha$-amylase, anti- $\alpha$-glucosidase, and COX inhibitory effects which could be a favorite candidate for the treatment of oxidative stress, microbial resistance, diabetes mellitus, and inflammatory diseases. Preclinical and clinical investigations are required to be conducted on the use of this plant species and further in-depth investigations are urgently crucial to explore the importance of such medicinal plants in pharmaceutical production.

Funding: This research did not receive any external funding.

Institutional Review Board Statement: Not applicable.

Informed Consent Statement: Not applicable.

Data Availability Statement: All data is contained within the article.

Acknowledgments: The author would like to knowledge An-Najah National University.

Conflicts of Interest: The author declares no conflict of interest.

Sample Availability: Sample of the Artemisia jordanica essential oil are available from the authors.

\section{References}

1. Yuan, H.; Ma, Q.; Ye, L.; Piao, G. The traditional medicine and modern medicine from natural products. Molecules 2016, $21,559$. [CrossRef]

2. Wink, M. Modes of action of herbal medicines and plant secondary metabolites. Medicines 2015, 2, 251-286. [CrossRef] [PubMed]

3. Dhifi, W.; Bellili, S.; Jazi, S.; Bahloul, N.; Mnif, W. Essential oils' chemical characterization and investigation of some biological activities: A critical review. Medicines 2016, 3, 25. [CrossRef] [PubMed]

4. Sarkic, A.; Stappen, I. Essential oils and their single compounds in cosmetics-A critical review. Cosmetics 2018, 5, 11. [CrossRef]

5. Amorati, R.; Foti, M.C. Mode of Antioxidant Action of Essential Oils; Wiley Online Library: Hoboken, NJ, USA, 2017 ; pp. 267-291. 
6. Costa, G.; Gidaro, M.C.; Vullo, D.; Supuran, C.T.; Alcaro, S. Active components of essential oils as anti-obesity potential drugs investigated by in silico techniques. J. Agric. Food Chem. 2016, 64, 5295-5300. [CrossRef] [PubMed]

7. Rashed, A.A.; Mohd Nawi, M.N.; Sulaiman, K. Assessment of essential oil as a potential anti-obesity agent: A narrative review. J. Essent. Oil Res. 2017, 29, 1-10. [CrossRef]

8. Collaboration, E.R.F. Diabetes mellitus, fasting blood glucose concentration, and risk of vascular disease: A collaborative meta-analysis of 102 prospective studies. Lancet 2010, 375, 2215-2222. [CrossRef]

9. Mrabti, H.N.; Sayah, K.; Jaradat, N.; Kichou, F.; Ed-Dra, A.; Belarj, B.; Cherrah, Y.; Faouzi, M.E.A. Antidiabetic and protective effects of the aqueous extract of Arbutus unedo L. in streptozotocin-nicotinamide-induced diabetic mice. J. Complement. Integr. Med. 2018, 15. [CrossRef] [PubMed]

10. NCD Risk Factor Collaboration. Worldwide trends in diabetes since 1980: A pooled analysis of 751 population-based studies with 4.4 million participants. Lancet 2016, 387, 1513-1530. [CrossRef]

11. Akolade, J.O.; Usman, L.A.; Okereke, O.E.; Muhammad, N.O. Antidiabetic potentials of essential oil extracted from the leaves of Hoslundia opposita Vahl. J. Med. Food 2014, 17, 1122-1128. [CrossRef]

12. Abdollahi, M.; Salehnia, A.; Mortazavi, S.H.R.; Ebrahimi, M.; Shafiee, A.; Fouladian, F.; Keshavarz, K.; Sorouri, S.; Khorasani, R.; Kazemi, A. Antioxidant, antidiabetic, antihyperlipidemic, reproduction stimulatory properties and safety of essential oil of Satureja Khuzestanica in rat in vivo: A toxicopharmacological study. Med. Sci. Monit. 2003, 9, BR331-BR335.

13. Benkhayal, F.A.; El-Ageeli, W.; Ramesh, S.; Farg-hamd, M. Anti-hyperglycaemic effects of volatile oils extracted from Rosemarinus officinalis and Artemisia cinae in diabetic rats. J. Vet. Anim. Sci. 2009, 5, 216-218.

14. Hichri, F.; Omri, A.; Hossan, A.S.M.; Ben Jannet, H. Alpha-glucosidase and amylase inhibitory effects of Eruca vesicaria subsp. longirostris essential oils: Synthesis of new 1,2,4-triazole-thiol derivatives and 1,3,4-thiadiazole with potential inhibitory activity. Pharm. Biol. 2019, 57, 564-570. [CrossRef]

15. Cabral, C.; Efferth, T.; Pires, I.M.; Severino, P.; Lemos, M.F. Natural products as a source for new leads in cancer research and treatment. Evid.-Based Complement. Altern. Med. 2018, 2018. [CrossRef]

16. Nazzaro, F.; Fratianni, F.; De Martino, L.; Coppola, R.; De Feo, V. Effect of essential oils on pathogenic bacteria. Pharmaceuticals 2013, 6, 1451-1474. [CrossRef]

17. Arora, M.; Choudhary, S.; Singh, P.K.; Sapra, B.; Silakari, O. Structural investigation on the selective COX-2 inhibitors mediated cardiotoxicity: A review. Life Sci. 2020, 251, 117631. [CrossRef]

18. An, B.-S.; Kang, J.-H.; Yang, H.; Jung, E.-M.; Kang, H.-S.; Choi, I.-G.; Park, M.-J.; Jeung, E.-B. Anti-inflammatory effects of essential oils from Chamaecyparis obtusa via the cyclooxygenase-2 pathway in rats. Mol. Med. Rep. 2013, 8, 255-259. [CrossRef] [PubMed]

19. Borges, R.S.; Ortiz, B.L.S.; Pereira, A.C.M.; Keita, H.; Carvalho, J.C.T. Rosmarinus officinalis essential oil: A review of its phytochemistry, anti-inflammatory activity, and mechanisms of action involved. J. Ethnopharmacol. 2019, 229, 29-45. [CrossRef] [PubMed]

20. Nigam, M.; Atanassova, M.; Mishra, A.P.; Pezzani, R.; Devkota, H.P.; Plygun, S.; Salehi, B.; Setzer, W.N.; Sharifi-Rad, J. Bioactive compounds and health benefits of Artemisia species. Nat. Prod. Commun. 2019, 14. [CrossRef]

21. Feinbrun-Dothan, N. Flora Palaestina; Academy of Sciences and Human: Jerusalem, Israel, 1978.

22. PubChem NIST Mass Spectrometry Data Center. Available online: https:/ / pubchem.ncbi.nlm.nih.gov/source/NIST\%20Mass\% 20Spectrometry\%20Data\%20Center (accessed on 13 January 2021).

23. Sharifi-Rad, J.; Sureda, A.; Tenore, G.C.; Daglia, M.; Sharifi-Rad, M.; Valussi, M.; Tundis, R.; Sharifi-Rad, M.; Loizzo, M.R.; Ademiluyi, A.O. Biological activities of essential oils: From plant chemoecology to traditional healing systems. Molecules 2017, 22, 70. [CrossRef]

24. Bendary, E.; Francis, R.; Ali, H.; Sarwat, M.; El Hady, S. Antioxidant and structure-activity relationships (SARs) of some phenolic and anilines compounds. Ann. Agric. Sci. 2013, 58, 173-181. [CrossRef]

25. Burt, S. Essential oils: Their antibacterial properties and potential applications in foods-A review. Int. J. Food Microbiol. 2004, 94, 223-253. [CrossRef] [PubMed]

26. Pino, J.A.; Rosado, A.; Fuentes, V. Chemical composition of the essential oil of Artemisia absinthium L. from Cuba. J. Essent. Oil Res. 1997, 9, 87-89. [CrossRef]

27. Nezhadali, A.; Akbarpour, M.; Shirvan, B.Z. Chemical composition of the essential oil from the aerial parts of Artemisia herba. J. Chem. 2008, 5, 557-561. [CrossRef]

28. Korolyuk, E.; Tkachev, A. Chemical composition of the essential oil from two wormwood species Artemisia frigida and Artemisia argyrophylla. Russ. J. Bioorganic Chem. 2010, 36, 884-893. [CrossRef]

29. Verma, M.K.; Anand, R.; Chisti, A.M.; Kitchlu, S.; Chandra, S.; Shawl, A.S.; Khajuria, R.K. Essential oil composition of Artemisia dracunculus L.(tarragon) growing in Kashmir-India. J. Essent. Oil-Bear. Plants 2010, 13, 331-335. [CrossRef]

30. Juteau, F.; Masotti, V.; Bessière, J.M.; Dherbomez, M.; Viano, J. Antibacterial and antioxidant activities of Artemisia annua essential oil. Fitoterapia 2002, 73, 532-535. [CrossRef]

31. Kordali, S.; Kotan, R.; Mavi, A.; Cakir, A.; Ala, A.; Yildirim, A. Determination of the chemical composition and antioxidant activity of the essential oil of Artemisia dracunculus and of the antifungal and antibacterial activities of Turkish Artemisia absinthium, A. dracunculus, Artemisia santonicum, and Artemisia spicigera essential oils. J. Agric. Food Chem. 2005, 53, 9452-9458.

32. Ćavar, S.; Maksimović, M.; Vidic, D.; Parić, A. Chemical composition and antioxidant and antimicrobial activity of essential oil of Artemisia annua L. from Bosnia. Ind. Crops Prod. 2012, 37, 479-485. [CrossRef] 
33. Diniz do Nascimento, L.; Moraes, A.A.B.D.; Costa, K.S.D.; Pereira Galúcio, J.M.; Taube, P.S.; Costa, C.M.L.; Neves Cruz, J.; de Aguiar Andrade, E.H.; Faria, L.J.G.D. Bioactive natural compounds and antioxidant activity of essential oils from spice plants: New findings and potential applications. Biomolecules 2020, 10, 988. [CrossRef]

34. Kim, S.; Lee, S.; Hong, C.; Gwak, K.; Park, M.; Smith, D.; Choi, I. Whitening and antioxidant activities of bornyl acetate and nezukol fractionated from Cryptomeria japonica essential oil. Int. J. Cosmet. Sci. 2013, 35, 484-490. [CrossRef]

35. El Jemli, M.; Kamal, R.; Marmouzi, I.; Doukkali, Z.; Bouidida, E.H.; Touati, D.; Nejjari, R.; El Guessabi, L.; Cherrah, Y.; Alaoui, K. Chemical composition, acute toxicity, antioxidant and anti-inflammatory activities of Moroccan Tetraclinis articulata L. J. Tradit. Complement. Med. 2017, 7, 281-287. [CrossRef]

36. Cutillas, A.-B.; Carrasco, A.; Martinez-Gutierrez, R.; Tomas, V.; Tudela, J. Composition and antioxidant, antienzymatic and antimicrobial activities of volatile molecules from Spanish Salvia lavandulifolia (Vahl.) essential oils. Molecules 2017, $22,1382$. [CrossRef] [PubMed]

37. Bhupathiraju, S.N.; Hu, F.B. Epidemiology of obesity and diabetes and their cardiovascular complications. Circ. Res. 2016, 118, 1723-1735. [CrossRef] [PubMed]

38. Lega, I.C.; Lipscombe, L.L. Diabetes, Obesity, and Cancer-Pathophysiology and Clinical Implications. Endocr. Rev. 2020, 41, 33-52. [CrossRef] [PubMed]

39. Roberts, M.F. Alkaloids: Biochemistry, Ecology, and Medicinal Applications; Springer: Berlin/Heidelberg, Germany, 2013.

40. Jaradat, N.; Qadi, M.; Abualhasan, M.N.; Al-lahham, S.; Al-Rimawi, F.; Hattab, S.; Hussein, F.; Zakarneh, D.; Hamad, I.; Sulayman, I. Carbohydrates and lipids metabolic enzymes inhibitory, antioxidant, antimicrobial and cytotoxic potentials of Anchusa ovata Lehm. from Palestine. Eur. J. Integr. Med. 2020, 34, 101066. [CrossRef]

41. Jaradat, N. Ethnopharmacological survey of natural products in Palestine. An-Najah Univ. J. Res. 2005, $19,13-67$.

42. Jugran, A.K.; Rawat, S.; Devkota, H.P.; Bhatt, I.D.; Rawal, R.S. Diabetes and plant-derived natural products: From ethnopharmacological approaches to their potential for modern drug discovery and development. Phytother. Res. 2020, 2020, 1-23. [CrossRef] [PubMed]

43. Jaradat, N.A. Medical plants utilized in Palestinian folk medicine for treatment of diabetes mellitus and cardiac diseases. Al-Aqsa Univ. J. 2005, 9, 1-28.

44. Cho, Y.-Y.; Baek, N.-I.; Chung, H.-G.; Jeong, T.-S.; Lee, K.T.; Jeon, S.-M.; Kim, H.-J.; McGregor, R.A.; Choi, M.-S. Randomized controlled trial of Sajabalssuk (Artemisia princeps Pampanini) to treat pre-diabetes. Eur. J. Integr. Med. 2012, 4, e299-e308. [CrossRef]

45. Olennikov, D.N.; Chirikova, N.K.; Kashchenko, N.I.; Nikolaev, V.M.; Kim, S.-W.; Vennos, C. Bioactive phenolics of the genus Artemisia (Asteraceae): HPLC-DAD-ESI-TQ-MS/MS profile of the Siberian species and their inhibitory potential against $\alpha$ amylase and $\alpha$-glucosidase. Front. Pharmacol. 2018, 9, 756. [CrossRef]

46. Hoey, J. Resistance movement. Aust. Pharm. 2018, 37, 30-39.

47. Osuntokun, O.; Ogunleye, A. Prospects of essential oils in drug discovery. Adv. Cytol. Pathol. 2017, 2, 17-19. [CrossRef]

48. Skała, E.; Rijo, P.; Garcia, C.; Sitarek, P.; Kalemba, D.; Toma, M.; Szemraj, J.; Pytel, D.; Wysokińska, H.; Śliwiński, T. The essential oils of Rhaponticum carthamoides hairy roots and roots of soil-grown plants: Chemical composition and antimicrobial, anti-inflammatory, and antioxidant activities. Oxid. Med. Cell Longev. 2016, 2016. [CrossRef] [PubMed]

49. Calo, J.R.; Crandall, P.G.; O’Bryan, C.A.; Ricke, S.C. Essential oils as antimicrobials in food systems-A review. Food Control 2015, 54, 111-119. [CrossRef]

50. Hyldgaard, M.; Mygind, T.; Meyer, R.L. Essential oils in food preservation: Mode of action, synergies, and interactions with food matrix components. Front. Microbiol. 2012, 3, 12-19. [CrossRef]

51. Amor, G.; Caputo, L.; La Storia, A.; De Feo, V.; Mauriello, G.; Fechtali, T. Chemical composition and antimicrobial activity of Artemisia herba-alba and Origanum majorana essential oils from Morocco. Molecules 2019, 24, 4021. [CrossRef]

52. Aati, H.Y.; Perveen, S.; Orfali, R.; Al-Taweel, A.M.; Aati, S.; Wanner, J.; Khan, A.; Mehmood, R. Chemical composition and antimicrobial activity of the essential oils of Artemisia absinthium, Artemisia scoparia, and Artemisia sieberi grown in Saudi Arabia. Arab. J. Chem. 2020, 13, 8209-8217. [CrossRef]

53. Das, S.; Vörös-Horváth, B.; Bencsik, T.; Micalizzi, G.; Mondello, L.; Horváth, G.; Kőszegi, T.; Széchenyi, A. Antimicrobial activity of different Artemisia essential oil formulations. Molecules 2020, 25, 2390. [CrossRef]

54. Dorman, H.D.; Deans, S.G. Antimicrobial agents from plants: Antibacterial activity of plant volatile oils. J. Appl. Microbiol. 2000, 88, 308-316. [CrossRef]

55. Rabib, H.; Elagdi, C.; Hsaine, M.; Fougrach, H.; Koussa, T.; Badri, W. Antioxidant and Antibacterial Activities of the Essential Oil of Moroccan Tetraclinis articulata (Vahl.) Masters. Biochem. Res. Int. 2020, 2020. [CrossRef]

56. Nathan, C. Points of control in inflammation. Nature 2002, 420, 846-852. [CrossRef]

57. Reddy, C.M.; Bhat, V.B.; Kiranmai, G.; Reddy, M.N.; Reddanna, P.; Madyastha, K. Selective inhibition of cyclooxygenase-2 by C-phycocyanin, a biliprotein from Spirulina platensis. Biochem. Biophys. Res. Commun. 2000, 277, 599-603. [CrossRef]

58. Jaradat, N. Quantitative estimations for the volatile oil by using hydrodistillation and microwave accelerated distillation methods from Ruta graveolens L. and Ruta chalepensis L. leaves from Jerusalem area/Palestine. Mor. J. Chem. 2016, 4, 1-6.

59. Tumuluru, J.S.; Sokhansanj, S.; Wright, C.T.; Kremer, T. GC Analysis of Volatiles and Other Products from Biomass Torrefaction Process; IntechOpen: London, UK, 2012; pp. 211-234. 
60. Jaradat, N.A.; Abualhasan, M. Comparison of phytoconstituents, total phenol contents and free radical scavenging capacities between four Arum species from Jerusalem and Bethlehem. Pharm. Sci. 2016, 22. [CrossRef]

61. Hawash, M.; Eid, A.M.; Jaradat, N.; Abualhasan, M.; Amer, J.; Naser Zaid, A.; Draghmeh, S.; Daraghmeh, D.; Daraghmeh, H.; Shtayeh, T.; et al. Synthesis and Biological Evaluation of Benzodioxole Derivatives as Potential Anticancer and Antioxidant agents. Heterocycl. Commun. 2020, 26, 157-167. [CrossRef]

62. Jaradat, N.; Zaid, A.; Hussein, F.; Zaqzouq, M.; Aljammal, H.; Ayesh, O. Anti-lipase potential of the organic and aqueous extracts of ten traditional edible and medicinal plants in Palestine; a comparison study with orlistat. Medicines 2017, 4, 89. [CrossRef]

63. Ali, H.; Houghton, P.; Soumyanath, A. $\alpha$-Amylase inhibitory activity of some Malaysian plants used to treat diabetes; with particular reference to Phyllanthus amarus. J. Ethnopharmacol. 2006, 107, 449-455. [CrossRef] [PubMed]

64. Hawash, M.; Jaradat, N.; Elaraj, J.; Hamdan, A.; Lebdeh, S.A.; Halawa, T. Evaluation of the hypoglycemic effect of seven wild folkloric edible plants from Palestine: (Antidiabetic effect of seven plants from Palestine). J. Altern. Complement. Med. 2019, 17. [CrossRef]

65. Jaradat, N.A.; Al-lahham, S.; Zaid, A.N.; Hussein, F.; Issa, L.; Abualhasan, M.N.; Hawash, M.; Yahya, A.; Shehadi, O.; Omair R.; et al. Carlina curetum plant phytoconstituents, enzymes inhibitory and cytotoxic activity on cervical epithelial carcinoma and colon cancer cell lines. Eur. J. Integr. Med. 2019, 30, 100933. [CrossRef]

66. Hawash, M.; Kahraman, D.C.; Cetin-Atalay, R.; Baytas, S. Induction of Apoptosis in Hepatocellular Carcinoma Cell Lines by Novel Indolylacrylamide Derivatives: Synthesis and Biological Evaluation. Chem. Biodivers. 2021. [CrossRef]

67. Balouiri, M.; Sadiki, M.; Ibnsouda, S.K. Methods for in vitro evaluating antimicrobial activity: A review. J. Pharm. Anal. 2016, 6, 71-79. [CrossRef]

68. Khalil, A.; Jaradat, N.; Hawash, M.; Issa, L. In vitro biological evaluation of benzodioxol derivatives as antimicrobial and antioxidant agents. Arab. J. Sci. Eng. 2021, 2021, 1-7. [CrossRef]

69. Jaradat, N.; Hawash, M.; Abualhasan, M. Synthesis and Biological Evaluation of Benzodioxol Derivatives as Cyclooxygenase Inhibitors. Lett. Drug Des. Discov. 2020, 17, 1117-1125. [CrossRef]

70. Hawash, M.; Jaradat, N.; Hameedi, S.; Mousa, A. Design, synthesis and biological evaluation of novel benzodioxole derivatives as COX inhibitors and cytotoxic agents. BMC Chem. 2020, 14, 1-9. [CrossRef] 